\title{
Reference values for maximum oxygen uptake relative to body mass in Dutch/Flemish subjects aged 6-65 years: the LowLands Fitness Registry
}

\author{
Geertje E. van der Steeg ${ }^{1} \cdot$ Tim Takken $^{2,3}$ (I)
}

Received: 23 October 2020 / Accepted: 10 January 2021 / Published online: 1 February 2021

(C) The Author(s) 2021

\begin{abstract}
Background The maximum oxygen uptake $\left(\mathrm{VO}_{2} \mathrm{max}\right)$ during cardiopulmonary exercise testing (CPET) is considered the best measure of cardiorespiratory fitness.

Aim To provide up-to-date reference values for the $\mathrm{VO}_{2}$ max per kilogram of body mass $\left(\mathrm{VO}_{2} \mathrm{max} / \mathrm{kg}\right)$ obtained by CPET in the Netherlands and Flanders.

Methods The Lowlands Fitness Registry contains data from health checks among different professions and was used for this study. Data from 4612 apparently healthy subjects, 3671 males and 941 females, who performed maximum effort during cycle ergometry were analysed. Reference values for the $\mathrm{VO}_{2} \mathrm{max} / \mathrm{kg}$ and corresponding centile curves were created according to the LMS method.

Results Age had a negative significant effect $(\mathrm{p}<.001)$ and males had higher values of $\mathrm{VO}_{2} \mathrm{max} / \mathrm{kg}$ with an overall difference of $18.0 \%$ compared to females.

Formulas for reference values were developed:

- Males: $\mathrm{VO}_{2} \mathrm{max} / \mathrm{kg}=-0.0049 \times \mathrm{age}^{2}+0.0884 \times$ age +4 $8.263\left(R^{2}=0.9859 ; \mathrm{SEE}=1.4364\right)$

- Females: $\mathrm{VO}_{2} \mathrm{max} / \mathrm{kg}=-0.0021 \times \mathrm{age}^{2}-0.1407 \times$ age $+43.066\left(R^{2}=0.9989 ;\right.$ SEE $\left.=0.5775\right)$.
\end{abstract}

Cross-validation showed no relevant statistical mean difference between measured and predicted values for males and a small but significant mean difference for females. We found remarkable higher $\mathrm{VO}_{2} \mathrm{max} / \mathrm{kg}$ values compared to previously published studies.

Conclusions This is the first study to provide reference values for the $\mathrm{VO}_{2} \mathrm{max} / \mathrm{kg}$ based on a Dutch/Flemish cohort. Our reference values can be used for a more accurate interpretation of the $\mathrm{VO}_{2} \mathrm{max}$ in the West-European population.

Keywords Reference values $\cdot$ Oxygen consumption $\cdot$ Cardiorespiratory fitness $\cdot$ Exercise test $\cdot$ Ergometry

\begin{tabular}{|c|c|c|c|}
\hline & & Abbrevia & tions \\
\hline & & BMI & Body mass index \\
\hline Cor & nmunicated by Jean-René Lacour. & CPET & Cardiopulmonary exercise testing \\
\hline$\triangle$ & Tim Takken & CVD & Cardiovascular diseases \\
\hline & t.takken@umcutrecht.nl & $\mathrm{HR}_{\max }$ & Maximum heart rate \\
\hline & & RER & Respiratory exchange ratio \\
\hline 1 & $\begin{array}{l}\text { Faculty of Medicine, Utrecht University, UMC Utrecht, } \\
\text { Utrecht, The Netherlands }\end{array}$ & $\mathrm{VO}_{2} \max$ & Maximum oxygen uptake \\
\hline 2 & Child Development \& Exercise, Wilhelmina Children's & & \\
\hline & Hospital, University Medical Center Utrecht, Room & & \\
\hline & KB02.056.0, PO Box 85090, NL 3508 AB Utrecht, & & \\
\hline & The Netherlands & & \\
\hline 3 & $\begin{array}{l}\text { The Physiology Academy, Alphen aan den Rijn, } \\
\text { The Netherlands }\end{array}$ & & \\
\hline
\end{tabular}




\section{Introduction}

Cardiorespiratory fitness (CRF) has been extensively studied in recent years, as the increase in cardiovascular diseases (CVD) is an expanding problem worldwide (Laxmi et al. 2014). Low levels of CRF have been identified as a potential risk factor for CVD and all-cause mortality; moreover, substantial health benefits might be gained by improvements in CRF, which can be obtained by physical activity and exercise (Rapp et al. 2018; Ross et al. 2016). Therefore, CRF is now identified as an important marker of cardiovascular health and has even been recommended as a new vital sign by the American Heart Association (Ross et al. 2016). Cardiopulmonary Exercise Testing (CPET) allows assessment of CRF. The measurement of the maximum amount of oxygen uptake during exercise, referred to as the $\mathrm{VO}_{2} \mathrm{max}$, is in particular relevant in evaluating an individual's aerobic fitness (Mezzani et al. 2009; Rapp et al. 2018; Takken et al. 2019) and is considered the best measure of CRF and exercise capacity (Fletcher et al. 2013).

In physiological terms, the $\mathrm{VO}_{2}$ max is the maximum level of oxygen uptake that can be consumed during exhausting exercise with large muscle groups (Fletcher et al. 2013; Herdy and Uhlendorf 2011; Mezzani et al. 2009). As a result, the $\mathrm{VO}_{2}$ level reaches a plateau phase. For this to happen, achievement of truly maximal effort is essential (Mezzani et al. 2009). An important component of the value of $\mathrm{VO}_{2} \max$, that is up to $50 \%$, is being established by hereditary capacity. However, there are several other determinants influencing the level of $\mathrm{VO}_{2}$ max, in particular age and sex, although body size, exercise training habits, lifestyle, and cardiovascular status play a role, as well (Almeida et al. 2014; Fletcher et al. 2013; Guazzi et al. 2012, 2018; Herdy and Caixeta 2016; Kaminsky et al. 2013; Koch et al. 2009; Mezzani et al. 2009; Ross et al. 2016; Takken et al. 2019). For instance, it has been observed that levels of $\mathrm{VO}_{2}$ max reach maximum values between the age of 15 and 30, and decrease progressively after that age. Furthermore, it has been found that males have higher levels of $\mathrm{VO}_{2}$ max compared to females, supposedly because of differences in muscle mass, haemoglobin levels, and cardiac stroke volume (Dubowy et al. 2008; Fletcher et al. 2013; Guazzi et al. 2012; Kaminsky et al. 2013; Koch et al. 2009; Mezzani et al. 2009; Takken et al. 2019).

Determining the level of $\mathrm{VO}_{2}$ max can be beneficial in different settings. For example, it can be used to assess the response to exercise training. Besides, the $\mathrm{VO}_{2} \mathrm{max}$ is convenient for evaluating $\mathrm{CRF}$ in patients with for instance heart or lung diseases as well as gauging their therapeutic efficacy and has been consistently determined a prognostic marker for pre-surgical risk. Furthermore, training intensity and training targets may be established by using percentages of $\mathrm{VO}_{2} \mathrm{max}$, which can be useful for healthy individuals and athletes, as well (Fletcher et al. 2013; Guazzi et al. 2018).

The $\mathrm{VO}_{2}$ max can be directly measured by incremental exercise using respiratory gas analysis, which is considered the golden standard (Almeida et al. 2014; Fletcher et al. 2013; Rapp et al. 2018; Ross et al. 2016; Takken et al. 2019). For the interpretation of a person's $\mathrm{VO}_{2} \max$, reliable reference values are extremely important. Due to the close correlation existing between the $\mathrm{VO}_{2}$ max and both age and sex, it is critical to interpret these values using age- and gender-specific reference values (Rapp et al. 2018).

Worldwide frequently used age- and gender-specific reference values are proposed by Jones et al. in 1985 and Wasserman et al. in 2005. However, these reference values were obtained years ago and were based on, respectively, Canadian and American cohorts. Nevertheless, in the Netherlands and other European countries, these reference values are still widely used, but in clinical practice, these are considered quite low, especially for young adults. Hence, up-to-date and dependable reference values based on a Dutch cohort are highly needed. Furthermore, most research in this area has focused on specific age groups, for instance children, elderly, or adults in general. Only few studies have provided reference values for a broader range of ages (Takken et al. 2019).

The aim of this study is to analyse the interaction between the $\mathrm{VO}_{2}$ max per kilogram $\left(\mathrm{VO}_{2} \mathrm{max} / \mathrm{kg}\right)$ and both age and sex and develop reference values using these two determinants, based on the Dutch population. For this purpose, we applied a large apparently healthy Dutch/Flemish cohort with a broad age range, including children from the age of 6 years to adults of 65 years.

\section{Methods}

\section{Study design}

This study was carried out using existing data from the LowLands Fitness Registry. This database contains exercise testing data from 11 centres in the Netherlands and Belgium. These centres include Diving Medical Center Den Helder, Erasmus Medical Center Rotterdam, Hospital Jan Portaels Vilvoorde, In2Motion Sports Bureau, InspanningLoont Centre Utrecht, Isala Hospital Zwolle, Maxima Medical Center Veldhoven, Ministry of Defense Testing Center Soesterberg, Radboud UMC Nijmegen, St Anna Hospital Geldrop, and University of Applied Sciences Utrecht. These centres submitted de-identified exercise testing data to the LowLands Fitness Registry. The Medical Ethics Committee of the 
UMC Utrecht in the Netherlands has approved the study (protocol 16/167) (Van de Poppe et al. 2019).

\section{Subjects}

For this study, we used data from 4637 subjects from the Lowlands Fitness Registry of which known athletes, smokers, and subjects with a Body Mass Index (BMI) > 30 were already excluded. From these subjects, we excluded the participants who did not perform a maximum effort, as well. A maximum effort was determined as a respiratory exchange ratio (RER) of $\geq 1.0$ (Kokkinos et al. 2018) and a minimum of $85 \%$ of the predicted maximum heart rate. We implemented Tanaka's equation for the prediction of maximum heart rate: $[208-(0.7 \times$ age $)]$ (Tanaka et al. 2001). Relevant subject characteristics and data distribution of the study participants are listed, respectively, in Tables 1 and 2.

\section{Testing protocol}

All exercise tests were performed using electromagnetically braked cycle ergometers. These ergometers came from distinctive manufacturers, that is Lode BV, Groningen, the Netherlands and Ergoline, Bitz, Germany (Van de Poppe

Table 1 Subject characteristics of the study population ${ }^{\mathrm{a}}$

\begin{tabular}{|c|c|c|c|c|c|c|c|c|}
\hline \multirow{2}{*}{$\begin{array}{l}\text { Characteris- } \\
\text { tics }\end{array}$} & \multicolumn{8}{|c|}{ Age categories (years) } \\
\hline & $\begin{array}{l}5-9(n=40 \\
\text { males, } 31 \\
\text { females })\end{array}$ & $\begin{array}{l}10-14 \\
(n=134 \\
\text { males, } 96 \\
\text { females })\end{array}$ & $\begin{array}{l}15-19 \\
(n=271 \\
\text { males, } 74 \\
\text { females })\end{array}$ & $\begin{array}{l}20-29 \\
(n=1127 \\
\text { males, } 244 \\
\text { females })\end{array}$ & $\begin{array}{l}30-39 \\
(n=934 \\
\text { males, } 246 \\
\text { females })\end{array}$ & $\begin{array}{l}40-49 \\
(n=809 \\
\text { males, } 164 \\
\text { females) }\end{array}$ & $\begin{array}{l}50-59 \\
(n=324 \\
\text { males, } 76 \\
\text { females })\end{array}$ & $\begin{array}{l}\geq 60(n=32 \\
\text { males, } 10 \\
\text { females })\end{array}$ \\
\hline \multicolumn{9}{|l|}{ Males } \\
\hline Age (years) & $8.83 \pm 0.93$ & $12.41 \pm 1.41$ & $18.33 \pm 1.43$ & $25.60 \pm 2.79$ & $35.01 \pm 2.89$ & $45.16 \pm 2.77$ & $53.94 \pm 2.43$ & $62.52 \pm 1.37$ \\
\hline Weight (kg) & $32.2 \pm 6.0$ & $45.3 \pm 9.8$ & $73.5 \pm 11.5$ & $80.9 \pm 9.1$ & $84.2 \pm 9.6$ & $85.3 \pm 9.3$ & $84.2 \pm 8.9$ & $81.4 \pm 9.5$ \\
\hline Height $(\mathrm{cm})$ & $138 \pm 7$ & $158 \pm 12$ & $181 \pm 7$ & $183 \pm 7$ & $183 \pm 7$ & $183 \pm 6$ & $182 \pm 6$ & $180 \pm 5$ \\
\hline BMI $\left(\mathrm{kg} / \mathrm{m}^{2}\right)$ & $16.9 \pm 2.1$ & $17.9 \pm 2.3$ & $22.4 \pm 2.9$ & $24.2 \pm 2.2$ & $25.1 \pm 2.3$ & $25.5 \pm 2.3$ & $25.5 \pm 2.2$ & $25.0 \pm 2.3$ \\
\hline \multicolumn{9}{|l|}{ Females } \\
\hline Age (years) & $8.83 \pm 0.71$ & $12.43 \pm 1.50$ & $17.57 \pm 1.61$ & $25.24 \pm 2.68$ & $35.30 \pm 2.93$ & $44.54 \pm 2.76$ & $54.22 \pm 2.78$ & $61.96 \pm 1.68$ \\
\hline Weight (kg) & $32.7 \pm 5.0$ & $48.1 \pm 11.6$ & $62.4 \pm 7.3$ & $66.6 \pm 7.7$ & $66.8 \pm 8.9$ & $69.0 \pm 8.3$ & $68.2 \pm 8.7$ & $69.5 \pm 5.3$ \\
\hline Height $(\mathrm{cm})$ & $139 \pm 8$ & $159 \pm 10$ & $171 \pm 6$ & $171 \pm 6$ & $170 \pm 6$ & $170 \pm 6$ & $168 \pm 6$ & $168 \pm 6$ \\
\hline BMI $\left(\mathrm{kg} / \mathrm{m}^{2}\right)$ & $17.0 \pm 1.8$ & $18.8 \pm 3.2$ & $21.4 \pm 2.2$ & $22.7 \pm 2.3$ & $23.0 \pm 2.6$ & $23.8 \pm 2.5$ & $24.3 \pm 2.6$ & $24.8 \pm 1.9$ \\
\hline
\end{tabular}

${ }^{\mathrm{a}}$ Data are presented as mean $\pm \mathrm{SD}$

Table 2 Data distribution in males and females ${ }^{\mathrm{a}}$

\begin{tabular}{|c|c|c|c|c|c|c|c|c|}
\hline \multirow{2}{*}{$\begin{array}{l}\text { Data distribu- } \\
\text { tion }\end{array}$} & \multicolumn{8}{|c|}{ Age categories (years) } \\
\hline & $\begin{array}{l}5-9(n=40 \\
\text { males, } 31 \\
\text { females })\end{array}$ & $\begin{array}{l}10-14 \\
(n=134 \\
\text { males, } 96 \\
\text { females })\end{array}$ & $\begin{array}{l}15-19 \\
(n=271 \\
\text { males, } 74 \\
\text { females })\end{array}$ & $\begin{array}{l}20-29 \\
(n=1127 \\
\text { males, } 244 \\
\text { females })\end{array}$ & $\begin{array}{l}30-39 \\
(n=934 \\
\text { males, } 246 \\
\text { females })\end{array}$ & $\begin{array}{l}40-49 \\
(n=809 \\
\text { males, } 164 \\
\text { females })\end{array}$ & $\begin{array}{l}50-59 \\
(n=324 \\
\text { males, } 76 \\
\text { females })\end{array}$ & $\begin{array}{l}\geq 60(n=32 \\
\text { males, } 10 \\
\text { females })\end{array}$ \\
\hline \multicolumn{9}{|l|}{ Males } \\
\hline $\begin{array}{l}\mathrm{VO}_{2} \max (\mathrm{ml} \\
\left.\min ^{-1} \mathrm{~kg}^{-1}\right)\end{array}$ & $45.86 \pm 5.94$ & $49.65 \pm 8.76$ & $50.63 \pm 7.97$ & $47.67 \pm 6.49$ & $45.50 \pm 7.62$ & $42.61 \pm 8.40$ & $38.50 \pm 8.97$ & $38.54 \pm 8.90$ \\
\hline HRmax (bpm) & $187 \pm 10$ & $190 \pm 8$ & $193 \pm 10$ & $189 \pm 10$ & $183 \pm 10$ & $175 \pm 11$ & $169 \pm 12$ & $162 \pm 11$ \\
\hline $\begin{array}{l}\operatorname{RER}\left(\mathrm{VCO}_{2} /\right. \\
\left.\mathrm{VO}_{2}\right)\end{array}$ & $1.12 \pm 0.07$ & $1.13 \pm 0.07$ & $1.16 \pm 0.08$ & $1.18 \pm 0.08$ & $1.18 \pm 0.08$ & $1.14 \pm 0.08$ & $1.13 \pm 0.08$ & $1.16 \pm 0.08$ \\
\hline \multicolumn{9}{|l|}{ Females } \\
\hline $\begin{array}{c}\mathrm{VO}_{2} \max (\mathrm{ml} \\
\left.\min ^{-1} \mathrm{~kg}^{-1}\right)\end{array}$ & $41.48 \pm 5.83$ & $42.00 \pm 6.46$ & $40.53 \pm 6.29$ & $39.51 \pm 8.76$ & $35.84 \pm 8.03$ & $34.19 \pm 8.66$ & $31.00 \pm 8.81$ & $29.45 \pm 7.83$ \\
\hline HRmax (bpm) & $189 \pm 8$ & $192 \pm 9$ & $190 \pm 8$ & $183 \pm 10$ & $176 \pm 10$ & $171 \pm 10$ & $167 \pm 12$ & $159 \pm 9$ \\
\hline $\begin{array}{l}\operatorname{RER}\left(\mathrm{VCO}_{2} /\right. \\
\left.\mathrm{VO}_{2}\right)\end{array}$ & $1.11 \pm 0.07$ & $1.15 \pm 0.07$ & $1.15 \pm 0.09$ & $1.13 \pm 0.09$ & $1.13 \pm 0.09$ & $1.14 \pm 0.08$ & $1.16 \pm 0.09$ & $1.17 \pm 0.08$ \\
\hline
\end{tabular}

${ }^{\mathrm{a}}$ Data are presented as mean $\pm \mathrm{SD}$ 
et al. 2019). The $\mathrm{VO}_{2}$ max was defined as the maximum amount of oxygen uptake during maximum effort measured around sea level and was expressed in $\mathrm{ml} \mathrm{min}^{-1} \mathrm{~kg}^{-1}$. This value was measured with a calibrated respiratory gasanalysis system. These systems were also from distinctive manufacturers, in particular from Cortex Metalyzer, Leipzig, Germany; Carefusion, Hoghberg, Germany; Geratherm, Bad Kissingen, Germany; Cosmed, Rome, Italy; and Medisoft, Sorrines, Belgium. The equipment was calibrated before every exercise test in accordance with the manufacturer's instruction (Van de Poppe et al. 2019).

\section{Statistical analysis}

Statistical analysis was performed using the SPSS Statistics software, version 25 (IBM Corp. Released 2017. IBM SPSS statistics for Windows, Version 25.0. Armonk, NY: IBM Corp.). Our data were modelled to create reference values using LMS Chartmaker Pro program ${ }^{\mathrm{TM}}$, version 2.54. This program works according to the LMS method, which is a way to summarize the distribution of the data as it changes via three curves representing the Lambda (L: the Box-Cox power describing the skewness), Median (M), and the generalised coefficient of variation (S). With a penalised likelihood function, the three curves were fitted as cubic splines using non-linear regression (Vamvakas et al. 2019; Van de Poppe et al. 2019). Hence, centile curves were created, representing the percentiles of P3 (lower limit of normal), P10, P25, P50 (median), P75, P90, and P97 (upper limit of normal). With Microsoft Excel version 2016, trend lines were added to the centile curves of the lower limit of normal, median, and upper limit of normal, describing the equation, $R$ square $\left(R^{2}\right)$, and standard error of the estimate (SEE) of the reference values. For cross validation, the paired samples $T$ test was performed in SPSS, to demonstrate the mean difference between the reference values and the actual measured data. $p$ values below 0.05 were considered as significant.

\section{Results}

\section{Subject characteristics}

Data from 4612 participants were eligible for analysis, involving 3671 males and 941 females. Descriptive characteristics of the participants, divided in both age categories of 10 years and sex, are given in Table 1 . Females had, as expected, lower weight and height than males. The measured values of $\mathrm{VO}_{2} \mathrm{max} / \mathrm{kg}$, maximum heart rate $\left(\mathrm{HR}_{\max }\right)$, and RER are listed in Table 2, by the same division in age categories and sex.

\section{Interaction with age and sex}

Univariate linear regression analysis shows a negative significant effect of age on the $\mathrm{VO}_{2} \mathrm{max} / \mathrm{kg}(p<0.001)$ for males as well as females. Figure 1 illustrates this decline of the $\mathrm{VO}_{2} \mathrm{max} / \mathrm{kg}$ with increasing age by
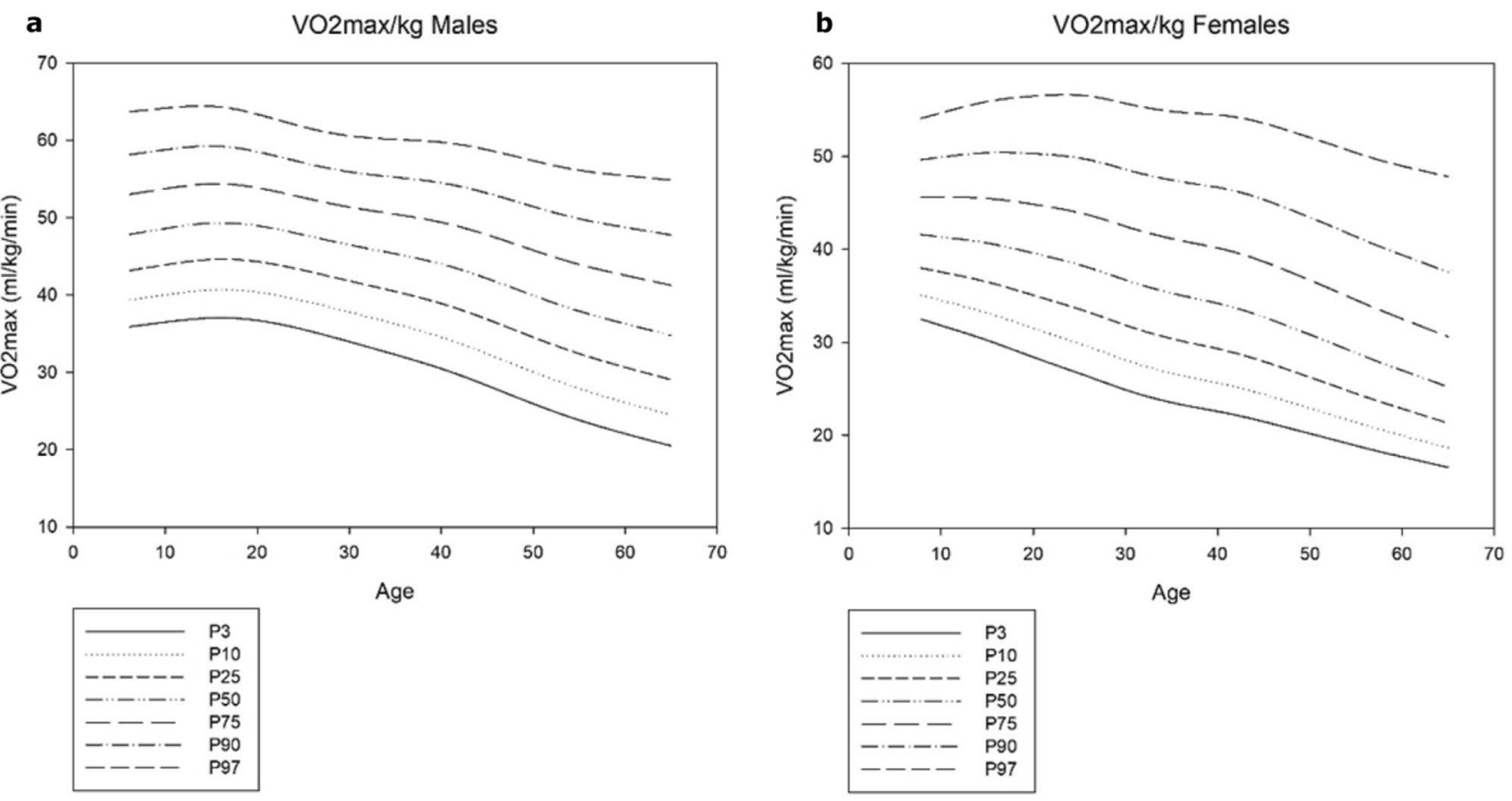

Fig. $1 \mathrm{VO}_{2} \max \left(\mathrm{ml} \mathrm{min}^{-1} \mathrm{~kg}^{-1}\right)$ according to age represented as P3, P10, P25, P50, P75, P90, and P97 in a males and b females 
applying centile curves. The mean value of $\mathrm{VO}_{2} \mathrm{max} / \mathrm{kg}$ was $45.39 \pm 8.33 \mathrm{ml} \mathrm{min}^{-1} \mathrm{~kg}^{-1}$ for males and $37.23 \pm 8.71$ for females. Consequently, the overall mean difference between males and females was $18.0 \%$, ranging from $9.6 \%$ for 5-9year old children to $23.5 \%$ for people above 60 years old.

\section{Reference values}

Reference values for the $\mathrm{VO}_{2} \mathrm{max} / \mathrm{kg}$ for both males and females were developed using the median (P50), the lower limit of normal (P3), and upper limit of normal (P97), and are depicted in Fig. 1. Table 3 displays the prediction equations with corresponding $R^{2}$ and SEE values. In Table 4 the reference values are compared with several previously published values for different ages.

\section{Cross-validation}

Supplementary data of 3135 subjects, who were not included in the primary analysis, were applied for performing cross validation. These data were derived from additional exercise tests performed at Diving Medical Center Den Helder. The sample consisted of 3017 males and 138 females.
Table 3 Reference equations for the $\mathrm{VO}_{2}$ max per kilogram

\begin{tabular}{llll}
\hline & Reference values & $R^{2}$ & SEE \\
\hline Males & & & \\
Median & $-0.0049 \times \mathrm{age}^{2}+0.0884 \times \mathrm{age}+48.263$ & 0.9859 & 1.4364 \\
Lower limit of normal & $0.0002 \times \mathrm{age}^{3}-0.0227 \times \mathrm{age}^{2}+0.5809 \times \mathrm{age}+31.909$ & 0.9996 & 1.4934 \\
Upper limit of normal & $0.00005 \times \mathrm{age}^{3}-0.0065 \times \mathrm{age}^{2}+0.0655 \times \mathrm{age}+64.801$ & 0.9758 & 0.5529 \\
Females & & & \\
Median & $-0.0021 \times \mathrm{age}^{2}-0.1407 \times \mathrm{age}+43.066$ & 0.9989 & 0.5775 \\
Lower limit of normal & $0.0017 \times \mathrm{age}^{2}-0.3995 \times \mathrm{age}^{2}+35.084$ & 0.9982 & 0.4981 \\
Upper limit of normal & $0.0001 \times \mathrm{age}^{3}-0.0153 \times \mathrm{age}^{2}+0.5674 \times \mathrm{age}+51.612$ & 0.9894 & 1.3213 \\
\hline
\end{tabular}

\begin{tabular}{|c|c|c|c|c|c|c|c|c|}
\hline \multirow[t]{2}{*}{ Reference values } & \multicolumn{8}{|c|}{ Age (years) } \\
\hline & 8 & 12 & 20 & 30 & 40 & 50 & 60 & 70 \\
\hline \multicolumn{9}{|l|}{ Males } \\
\hline Jones $^{\mathrm{a}}$ & $\mathrm{x}$ & $\mathrm{x}$ & 46.2 & 41.8 & 37.4 & 33.0 & 28.6 & 24.2 \\
\hline Wasserman $^{\mathrm{b}}$ & $\mathrm{x}$ & $\mathrm{x}$ & 43.3 & 39.6 & 35.8 & 32.1 & 28.4 & 24.7 \\
\hline $\operatorname{Koch}(\mathrm{SHIP})^{\mathrm{c}}$ & $\mathrm{x}$ & $\mathrm{x}$ & $\mathrm{x}$ & 35.9 & 33.8 & 31.2 & 32.2 & 29.3 \\
\hline Cooper $^{\mathrm{d}}$ & 43.4 & 46.1 & $\mathrm{x}$ & $\mathrm{x}$ & $\mathrm{x}$ & $\mathrm{x}$ & $\mathrm{x}$ & $\mathrm{x}$ \\
\hline Our study & 48.7 & 48.6 & 48.1 & 46.5 & 44.0 & 40.4 & 35.9 & 30.4 \\
\hline \multicolumn{9}{|l|}{ Females } \\
\hline Jones $^{\mathrm{a}}$ & $\mathrm{x}$ & $\mathrm{x}$ & 35.8 & 32.2 & 28.6 & 25.0 & 21.4 & 17.8 \\
\hline Wasserman $^{\mathrm{b}}$ & $\mathrm{x}$ & $\mathrm{x}$ & 31.8 & 29.0 & 25.9 & 23.2 & 20.3 & 17.6 \\
\hline SHIP $^{c}$ & $\mathrm{x}$ & $\mathrm{x}$ & $\mathrm{x}$ & 29.3 & 28.1 & 26.4 & 24.3 & 21.7 \\
\hline Cooper $^{\mathrm{d}}$ & 37.3 & 34.5 & $\mathrm{x}$ & $\mathrm{x}$ & $\mathrm{x}$ & $\mathrm{x}$ & $\mathrm{x}$ & $\mathrm{x}$ \\
\hline Our study & 41.8 & 41.1 & 39.4 & 37.0 & 34.1 & 30.8 & 27.1 & 22.9 \\
\hline
\end{tabular}

a Jones et al. (1985): $\mathrm{VO}_{2} \mathrm{max} / \mathrm{kg}=55-0.44 \times$ age (years) for males and $\mathrm{VO}_{2} \mathrm{max} / \mathrm{kg}=43-0.36 \times$ age (years) for females (Jones et al. 1985)

${ }^{\mathrm{b}}$ Wasserman et al. (2005): $\quad \mathrm{VO}_{2} \mathrm{max}=$ weight $(\mathrm{kg}) \times[50.72-(0.372 \times$ age $)]$ for males and $\mathrm{VO}_{2} \max =($ weight +42.8$) \times(22.78-0.17 \times$ age $)$ for females (Wasserman et al. 2005). For a reliable comparison, the mean weight of the subjects in our dataset was used for those ages, which are shown in Table 1

${ }^{c}$ Koch et al. (SHIP) (2009): for the full equation, see Koch et al. (2009) There is no comparison possible for children, because the reference values in the SHIP study are built on age categories that start at 25 years. The values of BMI $\left(\leq 25\right.$ or $\left.>25 \mathrm{~kg} \mathrm{~m}^{-2}\right)$ were based on the mean BMI of our study population given in Table 1

${ }^{\mathrm{d}}$ Cooper et al. (1984): $\mathrm{VO}_{2} \mathrm{max}=52.8 \times$ weight $(\mathrm{kg})-303.4$ for boys and $\mathrm{VO}_{2} \mathrm{max}=28.5 \times$ weight $(\mathrm{kg})+288.2$ for girls (Cooper et al. 1984). The weight is based on the weight of our study population, as shown in Table 1

$\mathrm{x}$, reference values not suitable for this age 
Paired samples $t$ test demonstrates a mean difference of $0.03 \pm 6.59 \mathrm{ml} \mathrm{min}^{-1} \mathrm{~kg}^{-1}$ with a $p=0.781$, in favour of the predicted $\mathrm{VO}_{2} \max$ for males. For females, there is a small but significant mean difference of $-1.88 \pm 5.67 \mathrm{ml} \mathrm{min}^{-1} \mathrm{~kg}^{-1}$ with a $p<0.001$, due to higher measured than predicted values.

\section{Discussion}

The purpose of this study was to provide up-to-date reference values for the $\mathrm{VO}_{2} \mathrm{max} / \mathrm{kg}$ by analysing the correlation of the $\mathrm{VO}_{2} \mathrm{max} / \mathrm{kg}$ between both age and sex based on a Dutch and Flemish cohort. Data from the LowLands Fitness Registry were analysed, in which children and adults aged 6 until 65 who performed a maximal effort during exercise testing on a cycle ergometer were included.

Age showed a negative significant effect on the $\mathrm{VO}_{2} \mathrm{max} /$ $\mathrm{kg}(p<0.001)$ among both sexes. Males showed higher levels of $\mathrm{VO}_{2} \mathrm{max} / \mathrm{kg}$ with an overall mean difference of $18 \%$. This difference is comparable to the literature. Using the composite equation of Cooper and Storer (Cooper and Storer 2001), the mean sex difference in $\mathrm{VO}_{2}$ max is $16.6 \%$ at the age of 20. Our reference values were developed using the median (p50, centile curve). The lower limits of normal (p3) and upper limits of normal (p97) reference equation were established as well. These lower and upper limits are important to established normalcy of $\mathrm{VO}_{2}$ max.

Cross-validation with data not included in the primary analysis showed no statistical difference between the predicted values and the actual measured values for males (mean difference $0.03 \pm 6.59 \mathrm{ml} \mathrm{min}{ }^{-1} \mathrm{~kg}^{-1}, p=0.781$ ), which means that these reference values are reliable. For females, a statistical significance was found between the measured values and our reference values $\left(-1.88 \pm 5.67 \mathrm{ml} \mathrm{min}^{-1} \mathrm{~kg}^{-1}\right.$, $p<0.001)$, which means that our reference values predict lower values than the actual outcome. The problem might be the relatively small sample size of females available for cross validation, which is a 138 female subjects. Besides, a mean difference of $1.88 \mathrm{ml} \mathrm{min}{ }^{-1} \mathrm{~kg}^{-1}$, although statistical significant, is small and might be therefore not of clinical relevance.

When comparing the reference values of this study to previously published values based on cycle ergometer exercise testing, it is remarkable that our reference values are higher. There are several explanations for this difference. First of all, the reference values are based on different geographic cohorts, Canadian (Jones et al. 1985), American (Wasserman et al. 2005), and German (the SHIP study, Koch et al. 2009), while our study is based on a Dutch and Flemish cohort. Physical and cultural differences between these cohorts may account for differences in the $\mathrm{VO}_{2} \mathrm{max} / \mathrm{kg}$. For instance, the $\mathrm{VO}_{2} \max$ tends to expand with increasing height, and the Dutch population is proven to be the tallest in the world (NCD Risk Factor Collaboration 2017). Besides, the $\mathrm{VO}_{2} \max$ shows a decline with increasing body mass index (BMI) (Koch et al. 2009) and mean BMI is lower in the Netherlands, compared to Canada, Germany, and the USA (26.1 compared to, respectively, 27.3, 27.4, and $29.1 \mathrm{~kg} / \mathrm{m}^{2}$ ) (World Health Organization). In addition, since the $\mathrm{VO}_{2} \max$ is expressed in $\mathrm{ml} \mathrm{min}^{-1} \mathrm{~kg}^{-1}$, a lower body weight will lead to a higher value of $\mathrm{VO}_{2} \mathrm{max} / \mathrm{kg}$. From a cultural perspective, the use of cycling in daily transfers is the most prominent in the Netherlands, compared to the rest of the world (Buehler and Pucher 2012). This may have led to an advantage in performing cycle ergometry. Furthermore, 2 of the 11 centres that submitted data to the Lowlands Fitness Registry have a military background, meaning that the physical condition of their subjects is likely to be above average, which is associated with a higher $\mathrm{VO}_{2} \max$ (Fletcher et al. 2013), and may have led to higher reference values, as well. Of interest to note is the non-linear decline in $\mathrm{VO}_{2} \max$ with age for both males and females. Traditionally, regression equations for $\mathrm{VO}_{2} \max$ are often presented as a simple linear regression of $\mathrm{VO}_{2} \mathrm{max}$ with age (Cooper and Storer 2001). The results of the current study do not endorse this approach. We recommend to use a non-linear approach to model $\mathrm{VO}_{2}$ max data.

Where the studies described above only concern adults and elderly, a comparison for children is possible with the widely used data of Cooper et al. (1984). The Cooper study showed lower values, as well, but it must be noted that the difference between the Cooper study and our study is smaller than the difference between the studies discussed above and our study for boys, in particular for 12-year-old boys. However, the difference between the $\mathrm{VO}_{2}$ max values of girls between the current study and the Cooper data are as big as the difference between adult studies. A recent case study also observed that the Cooper values for $\mathrm{VO}_{2} \mathrm{max}$ in children are substantially lower compared to those previously published by our group (Waterfall et al. 2020).

Taking this comparison into consideration, it is impossible to ignore the remarkable differences between our study outcome and previously published reference values, especially for adults. This demonstrates and explains the clinical experience of the existing reference values being too low for the Dutch population. Therefore, this shows the importance of having access to population-specific reference values.

Besides providing population-specific reference values, the aim of this study was to provide up-to-date values, as well. However, it is questionable whether the reference values of, for instance, Jones et al. (1985) and Wasserman et al. (2005) are outdated. Worldwide, there is a tendency towards an increase in cardiovascular diseases, of which CRF is an important marker (Ross et al. 2016). Nevertheless, this trend 
does not automatically mean that the health standards need to be reduced, as well. Values that relate to a standard based on desirable health conditions are officially called criterionreferenced fitness standards (Welk et al. 2011).

For people with obesity, it is impractical to use the $\mathrm{VO}_{2} \mathrm{max} / \mathrm{kg}$, since dividing the absolute value of $\mathrm{VO}_{2} \max$ $\left(\mathrm{ml} \mathrm{min}{ }^{-1}\right)$ by a high body weight automatically leads to a low $\mathrm{VO}_{2} \mathrm{max} / \mathrm{kg}$. Our recommendation for people with obesity is describing the $\mathrm{VO}_{2} \mathrm{max}$ in absolute values $\left(\mathrm{ml} \mathrm{min}{ }^{-1}\right)$ instead of relative to body mass. Then, comparison with the values of Mylius et al. (2019) is possible, who provided absolute values for the $\mathrm{VO}_{2}$ max that were based on the LowLands Fitness Registry, as well. An alternative would be calculating a person's ideal body weight and then dividing the absolute value of $\mathrm{VO}_{2} \mathrm{max}$ by this ideal weight, after which comparison with our reference values is possible.

There are multiple strengths to this study. First of all, to our knowledge, this is the first study to provide reference values for the $\mathrm{VO}_{2}$ max/kg based on a Dutch and Flemish cohort. Second, we applied a relative substantial sample size to this study ( $n=4612)$, compared to, for instance, Jones et al. $(n=100)$ (Jones et al. 1985), Wasserman et al. $(n=77)$ (Wasserman et al. 2005), and Koch et al. $(n=1708)$ (Koch et al. 2009). The different centres that submitted data to the LowLands Fitness Registry are properly distributed among the Netherlands and Flanders, and hence, the reference values are broadly representative of the Netherlands and Flanders. Besides, the data were obtained through mandatory health checks among different professions instead of voluntary health checks; consequently, there is minor selection bias at which healthier people will participate in voluntary health checks (Van de Poppe et al. 2019). Subjects with a broad age range were included, so the reference values are suitable for both children and adults from 6 until 65 years of age.

There are also some limitations to this study that need to be acknowledged. The $\mathrm{VO}_{2} \mathrm{max} / \mathrm{kg}$ is the maximum amount of oxygen uptake during exercise, which is physiologically demonstrated by a plateau phase. However, during most exercise testing, the $\mathrm{VO}_{2} \mathrm{max} / \mathrm{kg}$ does not reach this plateau phase. This means that the $\mathrm{VO}_{2} \mathrm{max} / \mathrm{kg}$ is measured at an estimated maximum effort instead of at the physiological plateau phase. Therefore, it is possible that the definite physiological $\mathrm{VO}_{2} \mathrm{max} / \mathrm{kg}$ may be a fraction higher than the estimated $\mathrm{VO}_{2} \mathrm{max} / \mathrm{kg}$ used in our study. No verification procedure for $\mathrm{VO}_{2}$ max was performed (Poole and Jones 2017). Moreover, our data were obtained by mandatory health checks among different professions, for instance divers and militaries. These professions acquire good physical condition, and therefore, the cardiorespiratory fitness might be overestimated, compared to the general Dutch population. Furthermore, our database contained almost 4 times as many male subjects as female subjects, and hence, the accuracy of our reference values might be higher for males than females. Finally, there is a skew distribution of subjects among the different age categories, since the decades of $20 \mathrm{~s}$ through the $50 \mathrm{~s}$ are most represented.

To provide more reliable reference values for females, future research with more female subjects is needed. Another recommendation is including more subjects in the lowest and highest age categories, especially subjects of 4 until 10 years old and above 65 years, to provide reference values with more reliability for children and elderly, as well.

\section{Conclusions}

This study provided reference values for the $\mathrm{VO}_{2} \mathrm{max} / \mathrm{kg}$ using cycle ergometry as mode for CPET based on both age and sex, and showed reliable results during cross-validation testing, especially for males. Comparison demonstrated remarkable higher levels of $\mathrm{VO}_{2} \mathrm{max} / \mathrm{kg}$ using the reference values of our study than those of previous published studies. Therefore, our reference values should be able to result in more accurate interpretations of measured $\mathrm{VO}_{2} \mathrm{max} / \mathrm{kg}$ for specifically the West-European population.

Acknowledgements We would like to thank the participating centres for contributing exercise testing data. The LowLands Fitness Registry Study Group consists of: Geert van Beek MSc, Leendert van Galen MSc, Yvonne Hartman PhD, Joep van Kesteren MSc, Jeroen van Molinger MSc, Pieter-Jan van Ooi MD, Marieke van den Oord PhD, Robert Rozenberg MD, Marcel Schmitz MSc, Aernout Snoek MD, Jaap Stomphorst MD, Nicolle Verbaarschot MSc, and Harriet Wittink PhD.

Authors' contributions GS and TT contributed to the design of the study and the analysis and interpretation of the data. GS drafted the manuscript. TT critically revised the manuscript. All authors gave final approval and agree to be accountable for all aspects of work ensuring integrity and accuracy.

Funding This research received no specific grant from any funding agency in the public, commercial, or not-for-profit sectors.

\section{Compliance with ethical standards}

Conflict of interest The authors declare that there is no conflict of interest.

Open Access This article is licensed under a Creative Commons Attribution 4.0 International License, which permits use, sharing, adaptation, distribution and reproduction in any medium or format, as long as you give appropriate credit to the original author(s) and the source, provide a link to the Creative Commons licence, and indicate if changes were made. The images or other third party material in this article are included in the article's Creative Commons licence, unless indicated otherwise in a credit line to the material. If material is not included in the article's Creative Commons licence and your intended use is not permitted by statutory regulation or exceeds the permitted use, you will need to obtain permission directly from the copyright holder. To view a copy of this licence, visit http://creativecommons.org/licenses/by/4.0/. 


\section{References}

Almeida AE, Stefani Cde M, Nascimento JA, Almeida NM, Santos Ada C, Ribeiro JP, Stein R (2014) An equation for the prediction of oxygen consumption in a Brazilian population. Arq Bras Cardiol 103:299-307

Buehler R, Pucher J (2012) Walking and cycling in Western Europe and the United States: trends, policies, and lessons. TR News 280:34-42

Cooper CB, Storer TW (2001) Exercise testing and interpretation: a practical approach. Cambridge University Press, Cambridge

Cooper DM, Weiler-Ravell D, Whipp BJ, Wasserman K (1984) Aerobic parameters of exercise as a function of body size during growth in children. J Appl Physiol Respir Environ Exerc Physiol 56:628634. https://doi.org/10.1152/jappl.1984.56.3.628

Dubowy KO, Baden W, Bernitzki S, Peters B (2008) A practical and transferable new protocol for treadmill testing of children and adults. Cardiol Young 18:615-623. https://doi.org/10.1017/S1047 951108003181

Fletcher GF et al (2013) Exercise standards for testing and training: a scientific statement from the American Heart Association. Circulation 128:873-934. https://doi.org/10.1161/CIR.0b013e3182 $9 \mathrm{~b} 5 \mathrm{~b} 44$

Guazzi M et al (2012) EACPR/AHA Joint Scientific Statement. Clinical recommendations for cardiopulmonary exercise testing data assessment in specific patient populations. Eur Heart J 33:29172927. https://doi.org/10.1093/eurheartj/ehs221

Guazzi M, Arena R, Halle M, Piepoli MF, Myers J, Lavie CJ (2018) 2016 focused update: clinical recommendations for cardiopulmonary exercise testing data assessment in specific patient populations. Eur Heart J 39:1144-1161. https://doi.org/10.1093/eurhe artj/ehw180

Herdy AH, Caixeta A (2016) Brazilian cardiorespiratory fitness classification based on maximum oxygen consumption. Arq Bras Cardiol 106:389-395. https://doi.org/10.5935/abc.20160070

Herdy AH, Uhlendorf D (2011) Reference values for cardiopulmonary exercise testing for sedentary and active men and women. Arq Bras Cardiol 96:54-59. https://doi.org/10.1590/s0066-782x2 010005000155

Jones NL, Makrides L, Hitchcock C, Chypchar T, McCartney N (1985) Normal standards for an incremental progressive cycle ergometer test. Am Rev Respir Dis 131:700-708. https://doi.org/10.1164/ arrd.1985.131.5.700

Kaminsky LA et al (2013) The importance of cardiorespiratory fitness in the United States: the need for a national registry: a policy statement from the American Heart Association. Circulation 127:652-662. https://doi.org/10.1161/CIR.0b013e31827ee100

Koch B et al (2009) Reference values for cardiopulmonary exercise testing in healthy volunteers: the SHIP study. Eur Respir J 33:389397. https://doi.org/10.1183/09031936.00074208

Kokkinos P, Kaminsky LA, Arena R, Zhang J, Myers J (2018) A new generalized cycle ergometry equation for predicting maximal oxygen uptake: the Fitness Registry and the Importance of Exercise National Database (FRIEND). Eur J Prevent Cardiol 25:1077_ 1082. https://doi.org/10.1177/2047487318772667

Laxmi CC, Udaya IB, Vinutha Shankar S (2014) Effect of body mass index on cardiorespiratory fitness in young healthy males. Int $\mathbf{J}$ Scie Res Publ 4

Mezzani A et al (2009) Standards for the use of cardiopulmonary exercise testing for the functional evaluation of cardiac patients: a report from the Exercise Physiology Section of the European Association for Cardiovascular Prevention and Rehabilitation. Eur J Cardiovasc Prev Rehabil 16:249-267. https://doi.org/10.1097/ HJR.0b013e32832914c8

Mylius CF, Krijnen WP, van der Schans CP, Takken T (2019) Peak oxygen uptake reference values for cycle ergometry for the healthy Dutch population: data from the LowLands Fitness Registry. ERJ Open Res. https://doi.org/10.1183/23120541.00056-2018

NCD Risk Factor Collaboration (2017) Height, evolution of adult height over time. http://www.ncdrisc.org/data-downloads-heigh t.html. Accessed 2nd July 2020

Poole DC, Jones AM (2017) Measurement of the maximum oxygen uptake Vo2max: Vo2peak is no longer acceptable. J Appl Physiol 122:997-1002. https://doi.org/10.1152/japplphysiol.01063.2016

Rapp D, Scharhag J, Wagenpfeil S, Scholl J (2018) Reference values for peak oxygen uptake: cross-sectional analysis of cycle ergometrybased cardiopulmonary exercise tests of 10090 adult German volunteers from the Prevention First Registry. BMJ Open 8:e018697. https://doi.org/10.1136/bmjopen-2017-018697

Ross $\mathrm{R}$ et al (2016) Importance of assessing cardiorespiratory fitness in clinical practice: a case for fitness as a clinical vital sign: a scientific statement from the American Heart Association. Circulation 134:e653-e699. https://doi.org/10.1161/CIR.0000000000000461

Takken T, Mylius CF, Paap D, Broeders W, Hulzebos HJ, Van Brussel M, Bongers BC (2019) Reference values for cardiopulmonary exercise testing in healthy subjects - an updated systematic review. Expert Rev Cardiovasc Ther 17:413-426. https://doi. org/10.1080/14779072.2019.1627874

Tanaka H, Monahan KD, Seals DR (2001) Age-predicted maximal heart rate revisited. J Am Coll Cardiol 37:153-156

Vamvakas G, Norbury CF, Vitoratou S, Gooch D, Pickles A (2019) Standardizing test scores for a target population: the LMS method illustrated using language measures from the SCALES project. PLoS ONE 14:e0213492. https://doi.org/10.1371/journ al.pone. 0213492

Van de Poppe DJ, Hulzebos E, Takken T, Low-Land Fitness Registry Study g (2019) Reference values for maximum work rate in apparently healthy Dutch/Flemish adults: data from the LowLands fitness registry. Acta Cardiol 74:223-230. https://doi. org/10.1080/00015385.2018.1478763

Wasserman K, Hansen JE, Sue DY, Stringer W, Whipp BJ (2005) Principles of exercise testing and interpretation: including pathophysiology and clinical applications. 4 edn. Lippincott Williams \& Wilkins, Philadelphia, PA

Waterfall JL, Burns P, Shackell D, Pepke-Zaba J, Oates KE, Sylvester KP (2020) The risks of applying normative values in paediatric cardiopulmonary exercise testing: a case report. ERJ Open Res. https://doi.org/10.1183/23120541.00333-2020

Welk GJ, Going SB, Morrow JR Jr, Meredith MD (2011) Development of new criterion-referenced fitness standards in the FITNESSGRAM(R) program: rationale and conceptual overview. Am J Prev Med 41:S63-67. https://doi.org/10.1016/j.amepr e.2011.07.012

Publisher's Note Springer Nature remains neutral with regard to jurisdictional claims in published maps and institutional affiliations. 